\title{
Characterization of Digestates from Anaerobic Co-Digestion of Manioc Effluent, Human Urine and Cow Dung
}

\author{
Kpata-Konan Nazo Edith'1, Kouamé Yao Francis², Kouamé Kouamé Martin², Konan Koffi Felix ${ }^{2 *}$ \\ ${ }^{1}$ Department of Agroforestry/University Jean Lorougnon Guédé, Daloa, Côte d'Ivoire \\ ${ }^{2}$ Department of Environment/University Jean Lorougnon Guédé, Daloa, Côte d'Ivoire \\ Email: ^konanfelix@yahoo.fr
}

How to cite this paper: Edith, K.-K.N., Francis, K.Y., Martin, K.K. and Felix, K.K. (2019) Characterization of Digestates from Anaerobic Co-Digestion of Manioc Effluent, Human Urine and Cow Dung. Journal of Water Resource and Protection, 11, 777-788.

https://doi.org/10.4236/jwarp.2019.116047

Received: May 17, 2019

Accepted: June 27, 2019

Published: June 30, 2019

Copyright $\odot 2019$ by author(s) and Scientific Research Publishing Inc. This work is licensed under the Creative Commons Attribution International License (CC BY 4.0).

http://creativecommons.org/licenses/by/4.0/

(c) (i) Open Access

\begin{abstract}
This study focused on the characterization of digestates resulting from anaerobic digestion of manioc effluents from attiéké factories. Two types of digestate were characterized, one consisting of manioc effluent + urine and another composed of manioc effluent + urine + cow dung. As a result, these residues of bio-digestion rich in nutrients (NPK) can be used as agricultural fertilizer. Moreover, the determination of some microorganisms and heavy metals digestates allowed to better appreciate its fertilizing quality. These parameters remained in accordance with the quality standards of a digestate prescribed. These results show that digestates from anaerobic co-digestion of manioc effluents, urine and cow dung can be used without fear as an agricultural biofertilizer.
\end{abstract}

\section{Keywords}

Manioc Effluent, Human Urine, Cow Dung, Anaerobic Co-Digestion, Digestate

\section{Introduction}

Anaerobic digestion is now widely used around the world to reduce the pollutant loads of various types of organic waste [1] [2] [3] [4] [5]. Indeed, it is a natural process by which organic matter is transformed into gas by the action of microorganisms in the absence of oxygen. Realized in confined spaces still called digesters or reactors, the reactions of fermentation can be optimized and checked while reducing at least of half pollution load constituted by numerous biodegradable by-products. These include municipal or industrial solid waste, agro-food ef- 
fluents and livestock waste [6] [7].

These anaerobic treatment systems have the advantage of producing biogas, mainly composed of methane [8] [9] [10]. But, the parameters influencing the digestate's fertilizing properties as well as the mechanisms involved are not yet sufficiently specified.

This technology is increasingly recommended for the treatment of waste agro-industry, including factories of attiéké which develops largely in recent years in West Africa.

In addition, new agricultural production policies encourage green agriculture. The reuse of residues or digests obtained after anaerobic digestion is stable, deodorized, largely free of pathogens and is rich in nitrogen compounds [8] [11] [12]. This digestate can be used as an amendment or biofertilizer [13] [14] for green and sustainable agricultural production.

Indeed, the composition and the quality of the digestates depend on the substrate used as well as the efficiency of the anaerobic digestion. Also, it would be necessary to analyze the digestate in accordance with quality standards for healthy and efficient use in agriculture as biofertilizer.

The present work aims to determine the fertilizing quality of digestates from the anaerobic co-digestion of cassava effluents, human urine and cow dung through monitoring of physicochemical parameters, metallic trace elements and the identification of pathogenic bacteria.

\section{Material and Methods}

\subsection{Material}

The co-substrates used are manioc effluent, human urine and cow dung. Cassava effluent is a mixture of peeled cassava wash water and crushed cassava juice. The human urine used to enrich manioc effluent with nitrogen and to correct the $\mathrm{pH}$ of these effluents. Cow dung was used to inoculate the digester. All these co-substrates were collected in Daloacity (Côte d'Ivoire). The pH and temperature were measured using a Hanna Instrument $\mathrm{pH}$ meter.

\subsection{Sampling and Analysis of Digestates}

Two experimental reactors consist of metal drums, reactor 1 (R1), reactor 2 (R2), were used for anaerobic digestion. Reactor 1 were fed with a mixture of manioc effluent, urine and cow dung $(E+U+C)$. As for reactor 2, it was seeded with a mixture of manioc effluent and urine $(\mathrm{E}+\mathrm{U})$.

The samples to be analyzed were collected using a syringe with a capacity of $60 \mathrm{ml}$, collected in polyethylene $70 \mathrm{ml}$ flasks and stored in an ice-cold box. This cooler is then transported to the laboratory for physicochemical, microbiological and heavy metals analyzes. Samples are made initially once a month and in a second time after 3 months of operation of the digesters.

The Chemical Oxygen Demand (COD) was determined by the potassium dichromate oxidation method (NF T 90-101). Biochemical oxygen demand (BOD5) were obtained by the manometric method [15]. Total Kjeldahlnitrogen (TNK) 
was assayed by titrimetry after distillation of the selenium mineralized sample (NF T 90-010). Total phosphorus was determined after mineralization of the sample in the presence of sulfuric acid and sodium persulfate (NF T 90-023). Ammonium $\left(\mathrm{NH}_{4}^{+}\right)$was determined according to the AFNOR NF T90-015 standard [16]. The potassium $(\mathrm{P})$ analysis protocol used is the flame photometry method fed by an air-butane mixture [17].

The metallic trace elements (Copper, Iron, Nickel, plumb) are determined by argon plasma ionization source mass spectrophotometry [17]. The bacterial germs were determined according to the agar incorporation method. EMB agars, Hektoen, Rapid medium, MOSSEL medium were used respectively for the enumeration of total fecal coliforms (NF T90-414) and (NFT 90-416), Salmonella, Escherichia coli and Bacillus cereus [18].

Statistical analyses were performed by the software Paleotological Statistic (PAST) version 3.21 [19].

\section{Results}

\subsection{Physicochemical Parameters}

\subsection{1. $\mathrm{pH}$ and Temperature}

For both reactors, the $\mathrm{pH}$ values increase strongly before stabilizing. $\mathrm{pH}$ values for the $\mathrm{E}+\mathrm{U}$ digestate were ranged from 6.70 to 10.29 with an average of 8.29 (Figure 1(a)). For this reactor, the highest value was recorded on the $62^{\text {th }}$ day of the experiment. Concerning the $\mathrm{E}+\mathrm{U}+\mathrm{C}$ digestate, the $\mathrm{pH}$ ranged from 6.50 to 9.76 with an average of 8.14 (Figure $1(\mathrm{~b})$ ). The highest value of $\mathrm{pH}$ for this reactor was observed on the $98^{\text {th }}$ day of operation.

The temperatures recorded in the digestate varied between $23^{\circ} \mathrm{C}$ and $34.4^{\circ} \mathrm{C}$ for the $\mathrm{E}+\mathrm{U}$ digestate (Figure $2(\mathrm{a})$ ) with an average of $28.66^{\circ} \mathrm{C}$. At the $\mathrm{E}+\mathrm{U}+$ $\mathrm{C}$ digestate recorded, temperatures fluctuated between $23^{\circ} \mathrm{C}$ and $34.9^{\circ} \mathrm{C}$ (Figure 2 (b)) with an average of $29.40^{\circ} \mathrm{C}$.

\subsubsection{Chemical Oxygen Demand (COD) and Biochemical Oxygen Demand (BOD)}

On the whole, COD values decreased from 8610 to $272 \mathrm{mg} / \mathrm{L}$ for $\mathrm{E}+\mathrm{U}$ digestate (Figure 3(a)) with a reduction rate of $96.84 \%$ and 7290 to $254 \mathrm{mg} / \mathrm{L}$ for $\mathrm{E}+\mathrm{U}+$ Cdigestate with a reduction rate of $96.51 \%$. The COD values of the $\mathrm{E}+\mathrm{U}+\mathrm{C}$ digestate have significantly more important decreases than the $\mathrm{E}+\mathrm{U}$ digestate (Anova test; $\mathrm{p}<0.05$ ).

Concerning BOD, the concentrations dropped from 3444 to $109 \mathrm{mg} / \mathrm{L}$ (Figure $3(\mathrm{~b})$ ), is a reduction of $96.84 \%$ for the $\mathrm{E}+\mathrm{U}$ digestate and from 2916 to 50 $\mathrm{mg} / \mathrm{L}$, is a fall of $98.28 \%$ for the digestate $\mathrm{E}+\mathrm{U}+\mathrm{C}$ (Figure 3(b)). The concentrations of BOD did not show a significant difference (Anova test; $p>0.05$ ) from one digestate to another.

\subsubsection{Concentration of Total Nitrogen, Ammonium, Total Phosphorus and Potassium}

In the $\mathrm{E}+\mathrm{U}$ digestate, the concentration of Total Nitrogen (TN) (Figure 4(a)) 


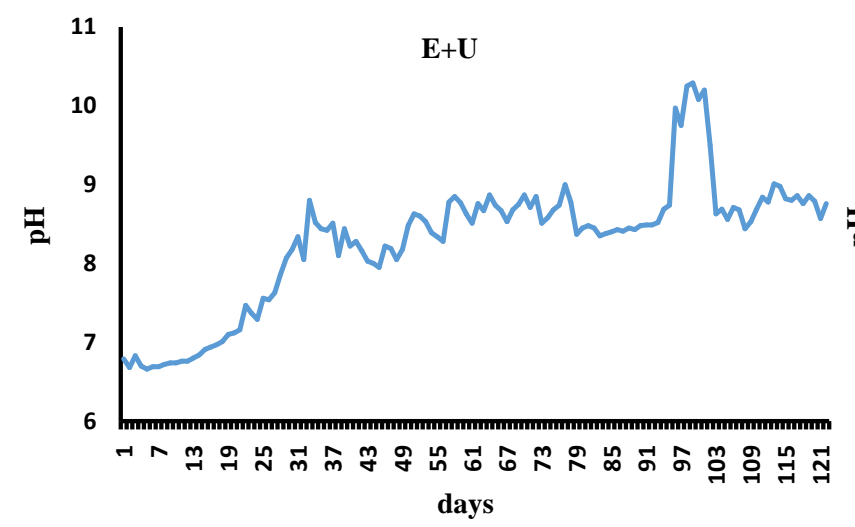

(a)

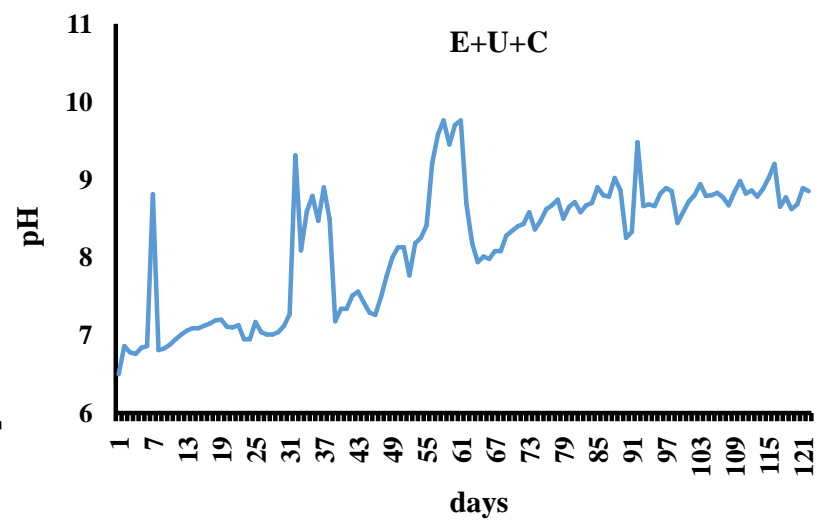

(b)

Figure 1. $\mathrm{pH}$ variation of digestates. (a) Reactor 1: $\mathrm{E}+\mathrm{U}+\mathrm{C}$ (mixture of manioc effluent, urine and cow dung); (b) reactor 2: $\mathrm{E}$ $+\mathrm{U}$ (mixture of manioc effluent and urine).

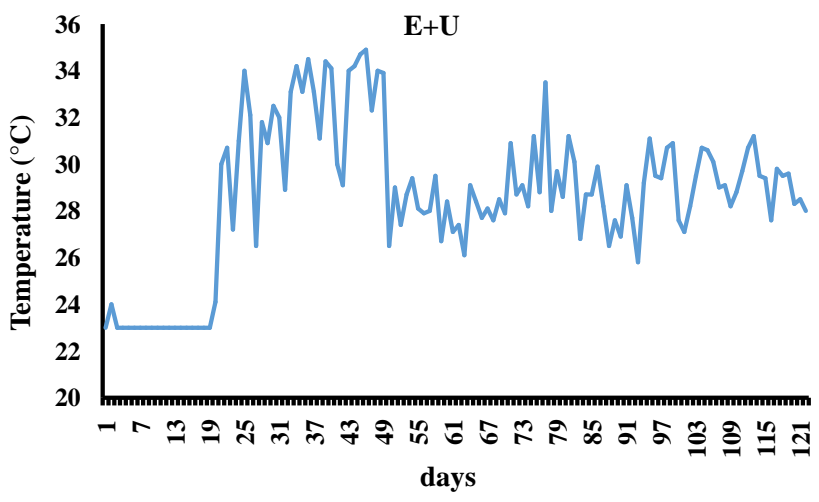

(a)

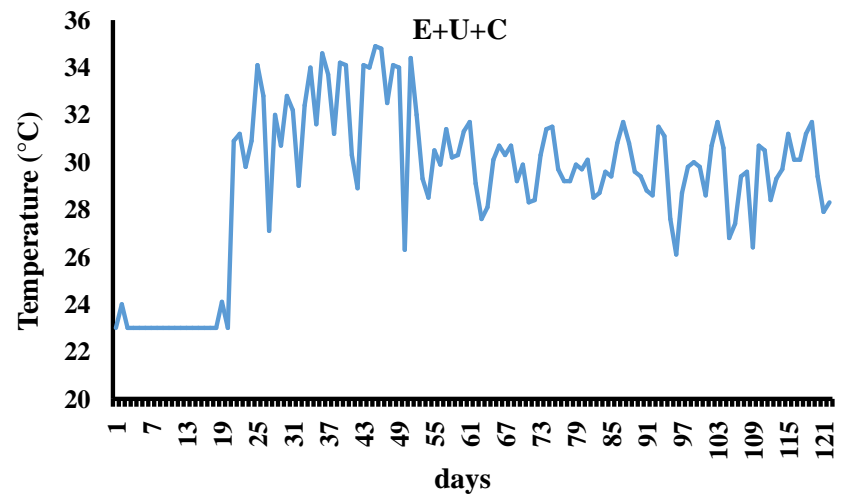

(b)

Figure 2. Variation of digestates temperatures. (a) Reactor 1: $\mathrm{E}+\mathrm{U}+\mathrm{C}$ (mixture of manioc effluent, urine and cow dung); (b) reactor 2: $\mathrm{E}+\mathrm{U}$ (mixture of manioc effluent and urine).

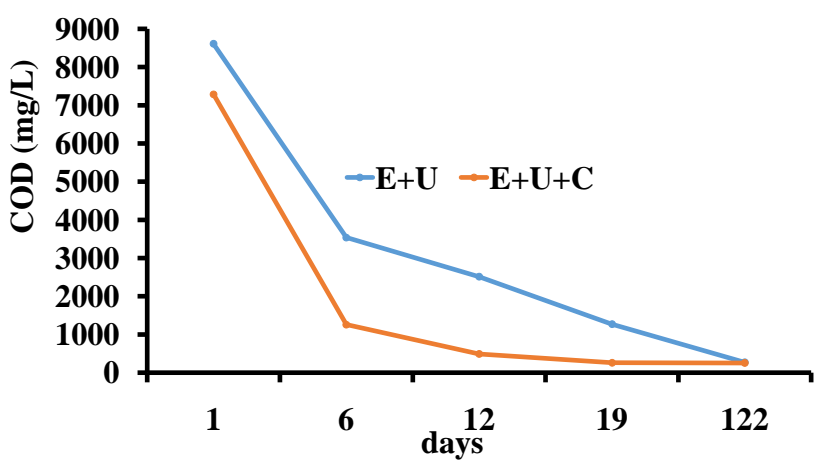

(a)

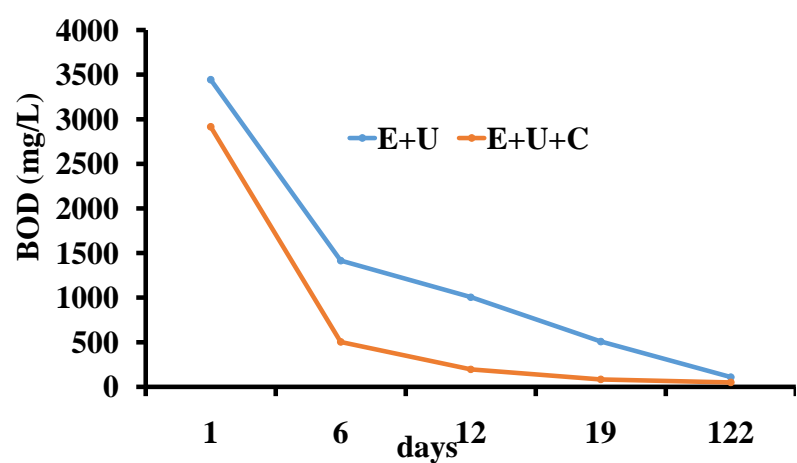

(b)

Figure 3. Variation of the COD (a) and BOD (b) of the digestates during the anaerobic digestion. Reactor 1 : $\mathrm{E}+\mathrm{U}+\mathrm{C}$ (mixture of manioc effluent, urine and cow dung); reactor 2: $\mathrm{E}+\mathrm{U}$ (mixture of manioc effluent and urine).

failed from 3251 to $2101 \mathrm{mg} / \mathrm{L}$ with an average of $2618.2 \mathrm{mg} / \mathrm{L}$. The values of Total Nitrogen in E + U + C digestate decreased from 3617 to $3145 \mathrm{mg} / \mathrm{L}$ with an average of $3412.4 \mathrm{mg} / \mathrm{L}$ (Figure $4(\mathrm{a})$ ). For this parameter, no significant difference (Anova test; $p>0.05$ ) was observed between the two types of digestates. 


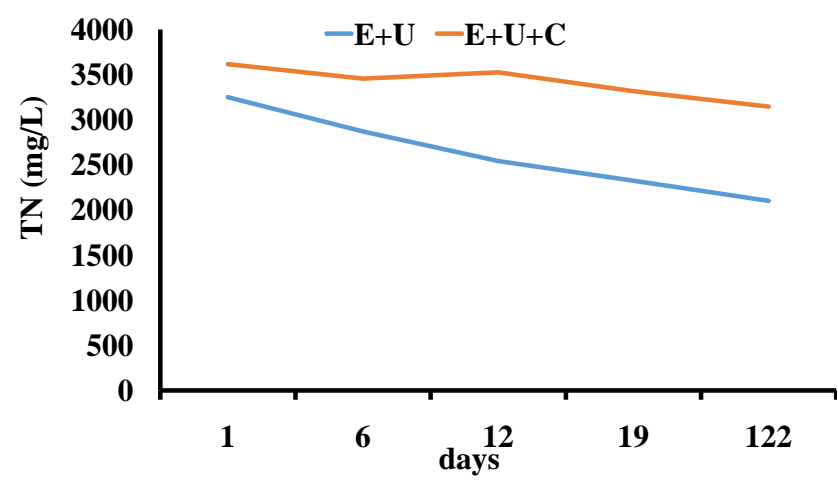

(a)

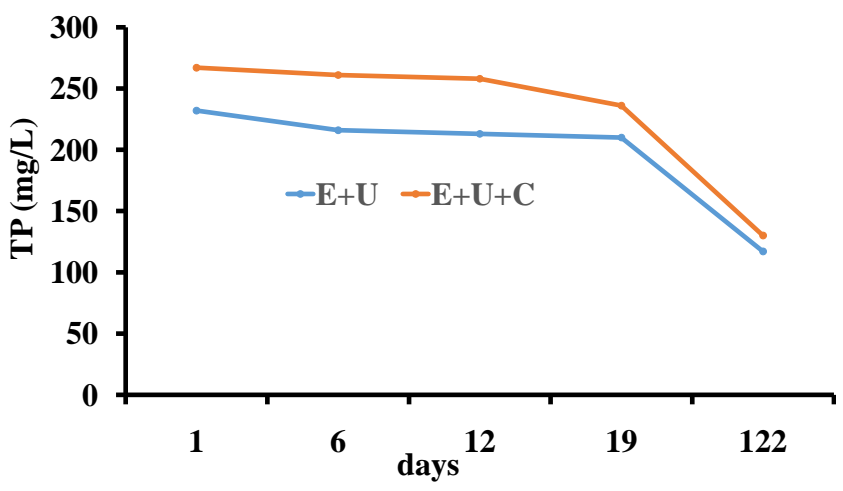

(c)

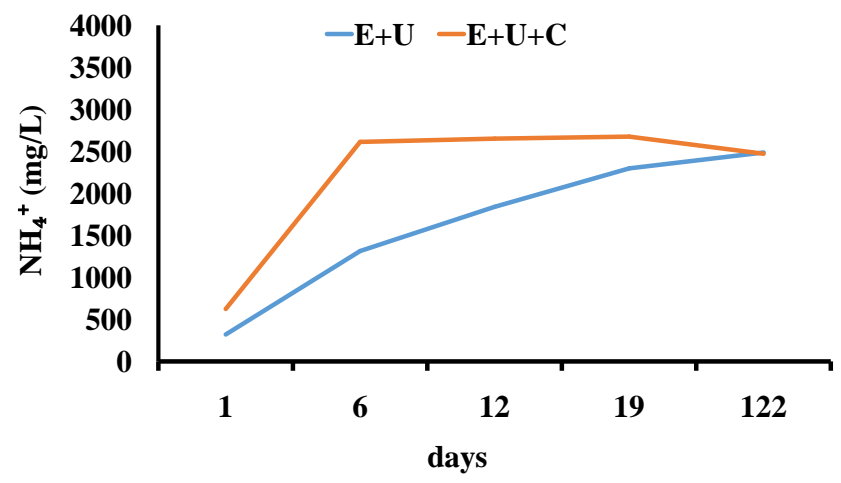

(b)

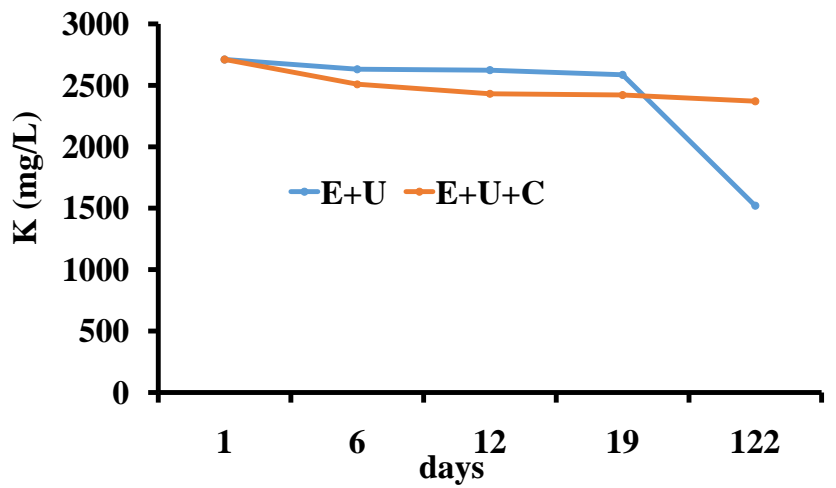

(d)

Figure 4. Evolution of nutrients in digestates during the anaerobic digestion. Reactor 1: $\mathrm{E}+\mathrm{U}+\mathrm{C}$ (mixture of manioc effluent, urine and cow dung); reactor 2: $\mathrm{E}+\mathrm{U}$ (mixture of manioc effluent and urine): (a) Total Nitrogen (TN); (b) ammonium ( $\mathrm{NH}_{4}^{+}$); (c) Total Phosphorus (TP); (d) potassium (K).

Concerning the ammonium values, the concentrations increased in $\mathrm{E}+\mathrm{U}$ digestate from 321 to $2487 \mathrm{mg} / \mathrm{L}$ with an average of $1651.6 \mathrm{mg} / \mathrm{L}$ (Figure $4(\mathrm{~b})$ ). For the E + U + C digestate, the growth observed varies from 624 to $2472 \mathrm{mg} / \mathrm{L}$ (Figure 4(b)), with an average of $2207 \mathrm{mg} / \mathrm{L}$. Statistical analyses revealed no significant difference (Anova test; $\mathrm{p}>0.05$ ) of $\mathrm{NH}_{4}^{+}$in digestates.

As for Total Phosphorus (TP), concentrations evolved from 232 to $217 \mathrm{mg} / \mathrm{L}$ for $\mathrm{E}+\mathrm{U}$ with an average of $217.6 \mathrm{mg} / \mathrm{L}$ (Figure $4(\mathrm{c})$ ). In the digestates from $\mathrm{E}$ $+\mathrm{U}+\mathrm{C}$, the phosphate values were changed from 267 to $230 \mathrm{mg} / \mathrm{L}$ (Figure $4(c)$ ), with an average of $250.4 \mathrm{mg} / \mathrm{L}$. There is no significant difference in total phosphate concentrations (Anova test; $\mathrm{p}>0.05$ ) between digestates.

Regarding potassium (K), a decrease in concentrations was observed during anaerobic digestion. The $\mathrm{E}+\mathrm{U}$ digestate shows concentrations ranging from 2710 to $1520 \mathrm{mg} / \mathrm{L}$ with an average value of $2413.6 \mathrm{mg} / \mathrm{L}$ (Figure 4(d)). For the $\mathrm{E}+\mathrm{U}+\mathrm{C}$ digestate, the values decreased from 2710 to $2770 \mathrm{mg} / \mathrm{L}$ with an average of $2588 \mathrm{mg} / \mathrm{L}$ (Figure 4(d)). No significant difference (Anova test; $\mathrm{p}>0.05$ ) was observed between digestates for this parameter.

\subsection{Concentrations in Metallic Trace Elements}

Concerning Nickel, the analysis showed a slight variation in concentrations of 
0.77 to $1.53 \mathrm{mg} / \mathrm{L}$ in $\mathrm{E}+\mathrm{U}$ and 2.78 to $2.48 \mathrm{mg} / \mathrm{L}$ in $\mathrm{E}+\mathrm{U}+\mathrm{C}$ (Figure 5(a)). For iron, a decrease was recorded from 5.89 to $2.69 \mathrm{mg} / \mathrm{L}$ in $\mathrm{E}+\mathrm{U}$ and 4.45 to $0.62 \mathrm{mg} / \mathrm{L}$ in $\mathrm{E}+\mathrm{U}+\mathrm{C}$ from day 1 to day 122 (Figure 5(b)). Copper levels observed in the $\mathrm{E}+\mathrm{U}$ digestate dropped from 0.01 to $0 \mathrm{mg} / \mathrm{l}$ until the end of the experiment (Figure 5(c)). For the $\mathrm{E}+\mathrm{U}+\mathrm{C}$ digestate, a slight decrease of Copper from 0.04 to $0.02 \mathrm{mg} / \mathrm{L}$ from day 1 to day 122 was recorded. As for plumb, the results showed values of $0.22 \mathrm{mg} / \mathrm{L}$ in $\mathrm{E}+\mathrm{U}$ digester and $0.03 \mathrm{mg} / \mathrm{L}$ in $\mathrm{E}+\mathrm{U}$ $+\mathrm{C}$ at day 1. These concentrations decreased to below the detection limit from day 19 to day 122 (Figure 5(c) and Figure 5(d)). Overall, heavy metals did not show a significant difference between the two types digestates.

\subsection{Microbiological Parameters}

Results on the microbiological quality of digestates (Figure 6(a) and Figure 6(b)) show that at day 1 samples contain a high concentration of germs. Fecal coliforms showed respective concentrations of $58.10^{5}$ and $145.10^{5} \mathrm{CFU} / 100 \mathrm{~mL}$ for the $\mathrm{E}+\mathrm{U}$ and $\mathrm{E}+\mathrm{U}+\mathrm{C}$ digests. For total coliforms, concentrations of $22.10^{5}$ $\mathrm{CFU} / 100 \mathrm{~mL}\left(\right.$ digestate $\mathrm{E}+\mathrm{U}$ ) and $134.10^{5} \mathrm{CFU} / 100 \mathrm{~mL}$ (digestate $\mathrm{E}+\mathrm{U}+\mathrm{C}$ )

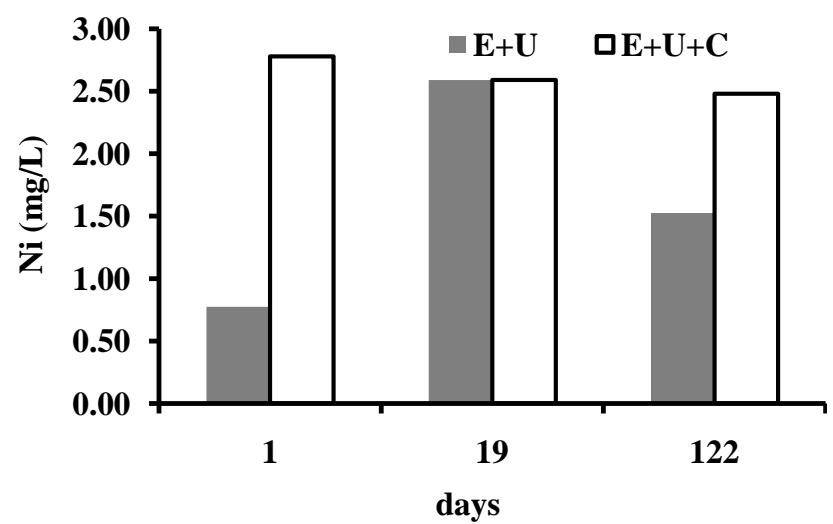

(a)

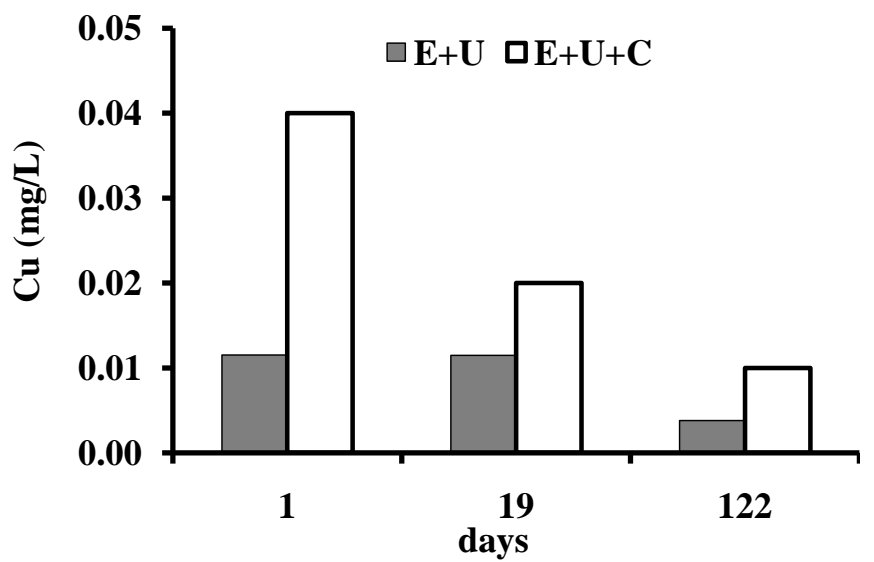

(c)

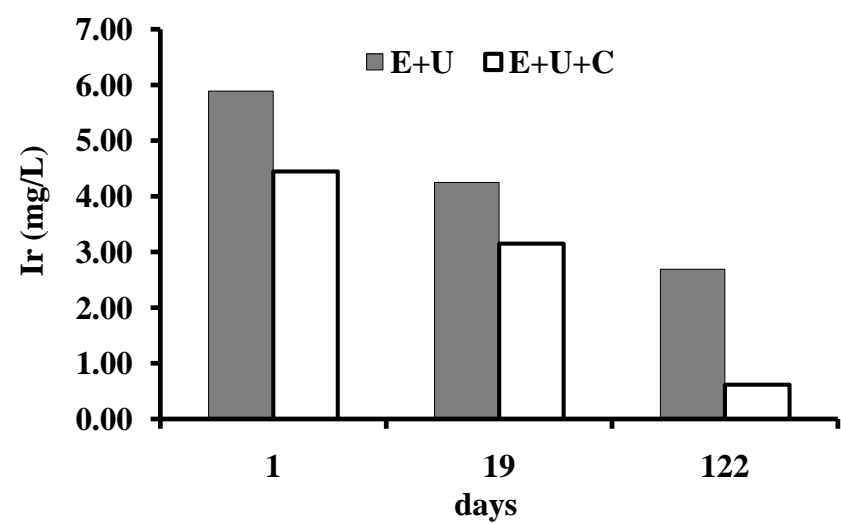

(b)

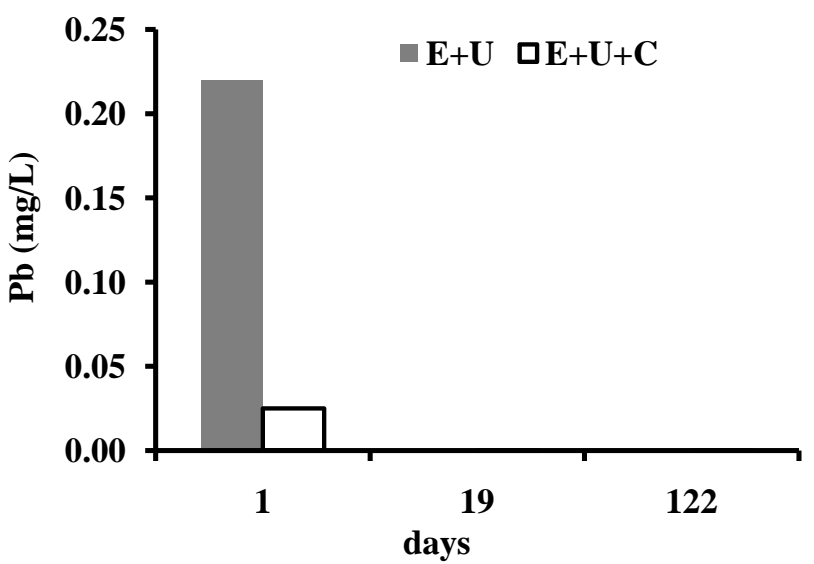

(d)

Figure 5. Contents of digestates in metallic elements during the anaerobic digestion. Reactor 1: $\mathrm{E}+\mathrm{U}+\mathrm{C}$ (mixture of manioc effluent, urine and cow dung); reactor 2: E + U (mixture of manioc effluent and urine): (a) Nickel (Ni); (b) Iron (Ir); (c) Copper $(\mathrm{Cu})$; (d) Plumb (Pb). 


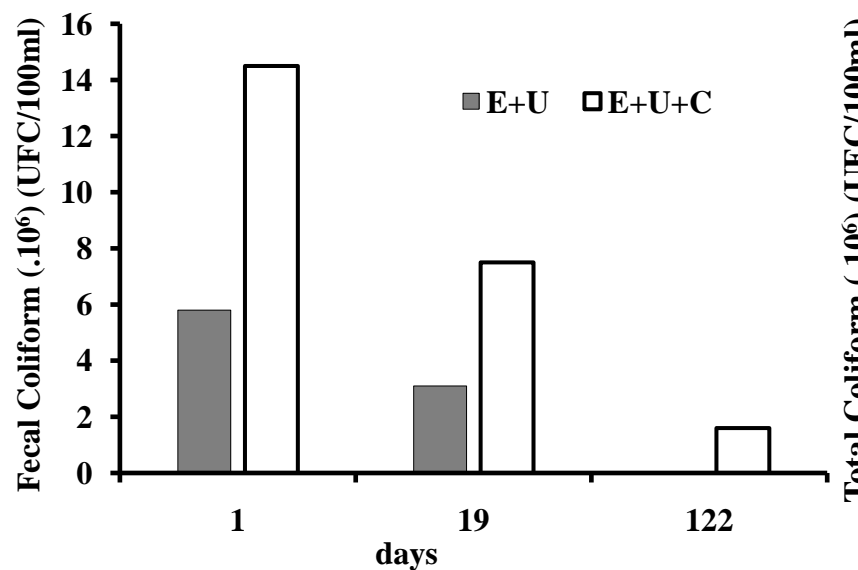

(a)

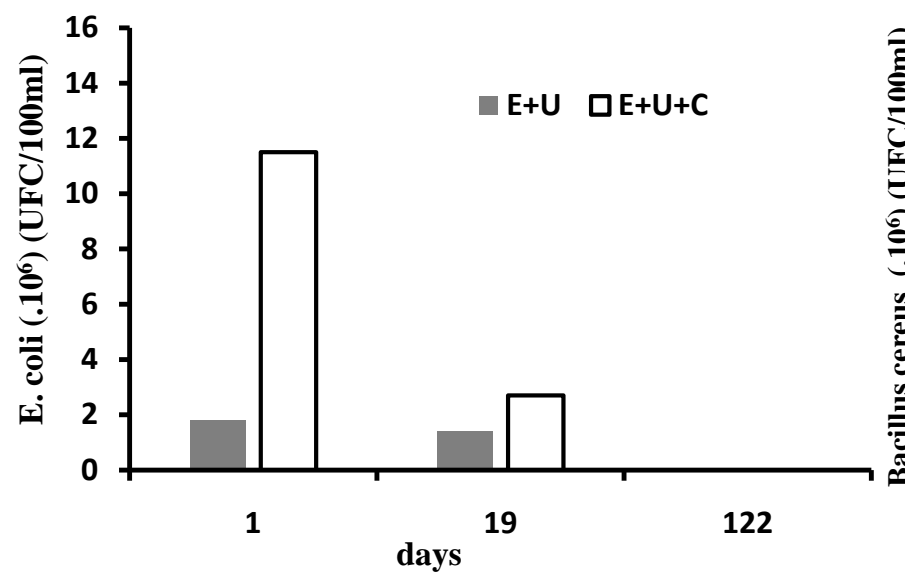

(c)

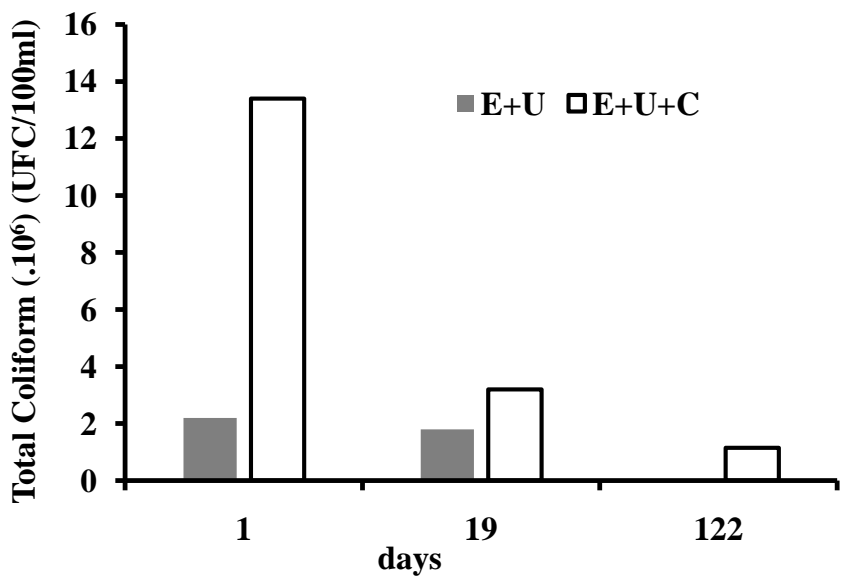

(b)

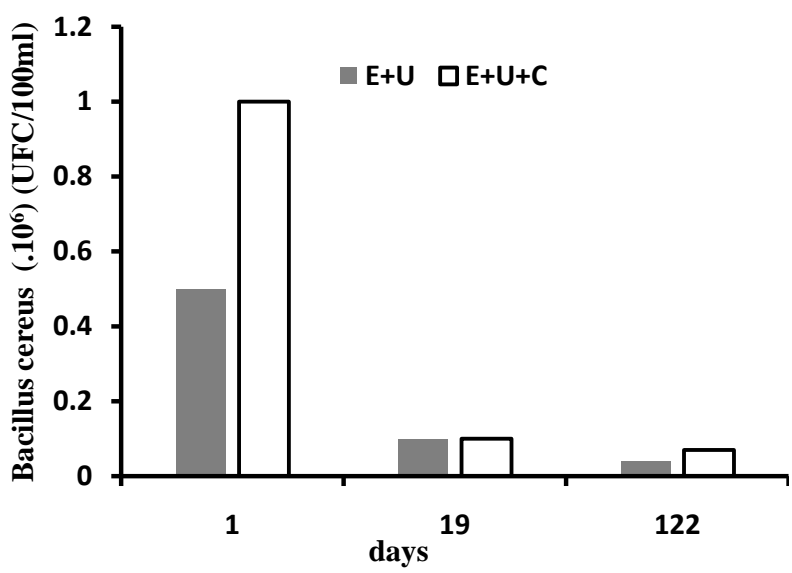

(d)

Figure 6. Variation of bacterial loads of digestates. Reactor 1: $\mathrm{E}+\mathrm{U}+\mathrm{C}$ (mixture of manioc effluent, urine and cow dung); reactor 2: E + U (mixture of manioc effluent and urine). (a) Fecal coliforms; (b) Total coliforms; (c) Escherichia coli; (d) Bacillus cereus.

were recorded. With regard to the germs of $E$. coli, the analyzes revealed concentrations of $18.10^{5} \mathrm{CFU} / 100 \mathrm{~mL}$ and $115.10^{5} \mathrm{CFU} / 100 \mathrm{~mL}$ respectively in the $\mathrm{E}$ $+\mathrm{U}$ and $\mathrm{E}+\mathrm{U}+\mathrm{C}$ digestates. High levels of Bacillus cereus with values of 5.105 $\mathrm{CFU} / 100 \mathrm{~mL}$ for $\mathrm{E}+\mathrm{U}$ and $1.106 \mathrm{CFU} / 100 \mathrm{~mL}$ for $\mathrm{E}+\mathrm{U}+\mathrm{C}$ were observed. The presence of Salmonella was also observed at $1^{\text {st }}$ day in the different substrates.

A reduction of the microbial load was observed from the $19^{\text {th }}$ day to the $122^{\text {nd }}$ day. Fecal coliforms decreased by $58.10^{5}$ at $00 \mathrm{CFU} / 100 \mathrm{~mL}$ for $\mathrm{E}+\mathrm{U}$ digestate and $145.10^{5}$ at $16.10^{5} \mathrm{CFU} / 100 \mathrm{~mL}$ for $\mathrm{E}+\mathrm{U}+\mathrm{C}$ digestate. At the level of total coliforms, an elimination of these germs from $22.10^{5}$ to $00 \mathrm{CFU} / 100 \mathrm{~mL}$ for $\mathrm{E}+$ $\mathrm{U}$ and from $134.10^{5}$ to $115.10^{4} \mathrm{CFU} / 100 \mathrm{~mL}$ for $\mathrm{E}+\mathrm{U}+\mathrm{C}$ was noted. As for $E$. coli, the reduction was respectively $18.10^{5}$ at $00 \mathrm{CFU} / 100 \mathrm{~mL}$ and $115.10^{5}$ at 00 $\mathrm{CFU} / 100 \mathrm{~mL}$ for $\mathrm{E}+\mathrm{U}$ and $\mathrm{E}+\mathrm{U}+\mathrm{C}$. Bacillus cereus showed a reduction of $5.10^{5} \mathrm{CFU} / 100 \mathrm{~mL}$ at $41.10^{4} \mathrm{CFU} / 100 \mathrm{~mL}$ for $\mathrm{E}+\mathrm{U}$ and $1.10^{6}$ at $7.105 \mathrm{CFU} / 100$ $\mathrm{mL}$ for $\mathrm{E}+\mathrm{U}+\mathrm{C}$. A total absence of Salmonella was also reported. 


\section{Discussion}

For $\mathrm{pH}$, analysis of the results obtained for the two types of digestates shows an average of 8.29 for $E+U$ and 8.14 for $E+U+C$. These values could be explained by the desorption of proteins or the volatilization of acidic compounds or $\mathrm{CO}_{2}$ during anaerobic digestion, as noted by [12] and [20]. These observations were also reported by [21] during their studies on the qualitative characterization of a liquid avicolic digestates derived from industrial biomethanization and use in fertigation of tomato plants.

The temperature of the digestates fluctuated in the range of mesophilic fermentation $\left(23^{\circ} \mathrm{C}\right.$ and $\left.35^{\circ} \mathrm{C}\right)$. This temperature is favored by the tropical climate characterized by strong sunshine and average annual temperatures of more than $26^{\circ} \mathrm{C}$ [9] [22] [23]. In this study, the reactors are displayed to the open air. According to [24], mesophilic fermentation is the most common and the best controlled systems.

Concerning COD and BOD, high levels are observed in digestates of the first day. The analysis of results show a major elimination of these pollutants in the digestate during the process. According to [25], the reduction of the pollutant load would be linked to the potential consumption of organic matter by the purifying microflora during its natural evolution in the digesters.

For the TKN, a slight decrease is observed in all digestates. This weak elimination indicates the conservation of TKN in reaction as also observed by [26]. The nitrogen contents of the digesters are similar to the values reported by [27]. According to this last author, a digestate designed to be used for the agricultural amendment must have a nitrogen content of between 1.5 and $6.2 \mathrm{~g} / \mathrm{Kg}$. For ammoniacal nitrogen, the increase observed in the reactors could be related to the mineralization of the organic nitrogen contained in the TKN in ammonium by the bacterial flora present in the digester [24] [28]. This transformation increases the fertilizing power of the digestate because plants much more easily assimilate it as source of nitrogen [28]. The elevation of $\mathrm{NH}_{4}{ }^{+}$is also thought to be due to the large production of amino acids after protein hydrolysis by proteolytic bacteria [24]. For [29], proteins allow specifying the fate of nitrogen in the anaerobic digester.

Regarding total phosphorus, the values revealed are slightly lower in the digestate. According to [30], this decrease could be explained by the solubilization of phosphorus to form mineral substances such as struvite and calcium phosphate (hydroxyapatite). Anaerobic digestion increases the availability of phosphorus and its efficiency in digestate [31]. However, for [32], no significant monitoring data can show an increase in soluble phosphorus in the digestate and [33] observes that the phosphorus values of a digestate are between 0.2 and 2.6 $\mathrm{g} / \mathrm{Kg}$. Presence of phosphorus in the digestate promotes root development, stiffness of the tissues, reproduction and the quality of the plant products [34].

As for potassium, the results showed a slight decrease for all digestates. Overall, co-digestion of manioc effluent, urine and cow dung produce a material rich in potassium. In fact, the average potassium contents of the digestate produced 
by the methanation are $2413.6 \mathrm{mg} / \mathrm{L}$ for the $\mathrm{E}+\mathrm{U}$ digestate and $2588 \mathrm{mg} / \mathrm{L}$ for the $\mathrm{E}+\mathrm{U}+\mathrm{C}$. These levels are higher than the minimum value reported by [27].

Concerning the metallic trace elements, the values recorded on the $1^{\text {st }}$ and the $122^{\text {nd }}$ day are in conformity with the standards described by the European Commission. According to [25], the heavy metals contents of digestates would be influenced by the origin of the substrates treated by anaerobic digestion. The heavy metal content of biofertilizers is one of the major concerns in their use in agriculture. Indeed, [25] believes that the use of a high metal biofertilizer can lead to soil contamination with the potential for metals to accumulate in plant roots, remain in the soil and pollute groundwater.

Regarding the microbiological characterization, the results showed a significant reduction of germs in the digestates. For total and fecal coliforms, their levels in digestates are lower than the standards set by the [35] for irrigation water. Concentrations of $E$. coli were below the thresholds set by European Union regulations indicating a value of less than $1000 \mathrm{CFU} / \mathrm{g}$ in 4 samples or less than $5000 \mathrm{CFU} / \mathrm{g}$ in a sample [36]. Bacillus cereus has lower rates than the threshold values of the European Commission regulations. Also, an absence of Salmonella has been recorded at the end of the experimentation period. This elimination of germs in the digestates would be related to the temperature and residence time pair. Indeed, the anaerobic digestion took place for 122 days in this study at an average temperature of $23^{\circ} \mathrm{C}$ corresponding to the mesophilic phase. According to [36], the time to reduce the population of pathogens by $90 \%$ is several days or even months at mesophilic temperatures. Because for a good hygienization of the digestates, it is necessary that the anaerobic digestion is done at $\mathrm{pH}$ close to the neutrality (6.8 to 8.5$)$, at mesophilic temperatures $\left(20^{\circ} \mathrm{C}\right.$ to $45^{\circ} \mathrm{C}$ with an optimum towards $35^{\circ} \mathrm{C}$ ) with residence times of 20 to 60 days [14] [25].

\section{Conclusion}

The digestates treated during this study are rich in nutrients and can be used as agricultural fertilizer. Moreover, the determination of certain microorganisms and heavy metals in the studied digestate allowed to better assess its fertilizing quality. These parameters remain in accordance with the quality standards of a biofertilizer prescribed by the European Commission. The results of this study show that digestate from anaerobic digestion of manioc effluent, urine and cow dung can be promoted in agriculture as a biofertilizer.

\section{Acknowledgements}

The authors thank the officials of University Jean Lorougnon Guédé, the attiéké manufacturing units and slaughterhouse in Daloa city (Côte d'Ivoire) where the different co-substrates (manioc effluent, human urine and cow dung) were collected for this study.

\section{Conflicts of Interest}

The authors declare no conflicts of interest regarding the publication of this paper. 


\section{References}

[1] Fountoulakis, M.S., Petousi, I. and Manios, T. (2010) Co-Digestion of Sewage Sludge with Glycerol to Boost Biogas Production. Waste Management, 30, 1849-1853. https://doi.org/10.1016/j.wasman.2010.04.011

[2] Kpata-Konan, N.E., Gnagne, T., Kouamé, F.Y., Konan, F.K., Kouamé, K.M. and Kablan, T. (2018) Optimum Amount of Inoculum for Anaerobic Digestion of Cassava Waste. Livestock Research for Rural Development, 30, 1-7.

http://www.lrrd.org/lrrd30/4/kano30060.html

[3] M'Sadak, Y., Ben M'Barek, A., Zoghlami, R.I. and Baraket, S. (2010) Valorisations environnementale et énergétique de la Biométhanisation appliquée aux effluents d'élevage. Affiche, $21^{\text {ème }}$. Mahdia, Tunisie, Forum International des Sciences Biologiques, ATSB, 15-18.

[4] Ubalua, A.O. (2007) Cassava Wastes: Treatment Options and Value Addition Alternatives. African Journal of Biotechnology, 6, 2065-2073. https://doi.org/10.5897/AJB2007.000-2319

[5] Zhu, Z., Hsueh, K.M. and He, Q. (2011) Enhancing Biomethanation of Municipal Waste Sludge with Grease Trap Waste as a Co-Substrate. Renewable Energy, 36, 1802-1807. https://doi.org/10.1016/j.renene.2010.11.014

[6] M'Sadak, Y., Ben M'Barek, A. and Baraket, S. (2010b) Agronomic Interest of the Residues of Rural Biomethanisation Applied to the Bovine Biomass. Displays, ISOFAR /MOAN Symposium. Soil Fertility and Crop Nutrition Management in Mediterranean Organic Agriculture, Sousse, Tunisia, March 2010, 23-25.

[7] Malekkhahi, M., Mesgaran, M.D. and Tahmasbi, A.M. (2012) The Effect of Chemical Treatment with $\mathrm{NaOH}$ and Urea on Chemical Composition, in Vitro Gas Production and in Situ Dry Matter Degradability of Sesame Residues. Livestock Research for Rural Development, 24, Article No. 224.

[8] Kalloum, S., Bouabdessalem, H., Touzi, A., Iddou, A. and Ouali, M.S. (2011) Biogas Production from the Sludge of the Municipal Wastewater Treatment Plant of Adrar city (Southwest of Algeria). Biomass and Bioenergy, 35, 2554-2560. https://doi.org/10.1016/j.biombioe.2011.02.012

[9] Kpata-Konan, N.E., Gnagne, T., Konan, K.F., Kouamé, K.M., Kouamé, Y.F. and Tano, K. (2015) Biogas Production from Anaerobic Co-Digestion of Cassava Effluent and Human Urine. Pakistan Journal of Biotechnology, 12, 93-98.

[10] Yen, H. and Brune, D.E. (2007)Anaerobic Co-Digestion of Algal Sludge and Waste Paper to Produce Methane. Bioresource Technology, 98, 130-134. https://doi.org/10.1016/j.biortech.2005.11.010

[11] Gomez-Lahoz, C., Fernandez-Gimenez, B., Garcia-Herruzo, F., Rodriguez-Görish, U. and Helm, M. (2006) La production de biogas. ULMER, Paris.

[12] Kpata-Konan, N.E., Konan, K.F., Kouamé, K.M., Kouamé, Y.F., Gnagne, T. and Tano, K. (2011) Optimisation de la biométhanisation des effluents de manioc issus de la filière de fabrication de l'attiéké (semoule de manioc). International Journal of Biological and Chemical Sciences, 5, 2330-2342. https://doi.org/10.4314/ijbcs.v5i6.13

[13] Madsen, M., Holm-Nielsen, J.B. and Esbensen, K.H. (2011) Monitoring of Anaerobic Digestion Processes: A Review Perspective. Renewable. Sustainable. Energy Reviews, 15, 3141-3155. https://doi.org/10.1016/j.rser.2011.04.026

[14] Sahlström. L. (2003) A Review of Survival of Pathogenic Bacteria in Organic Waste Used in Biogas Plants. Bioresource Technology, 87, 161-166. 
https://doi.org/10.1016/S0960-8524(02)00168-2

[15] AFNOR (Association Française de Normalisation) (2001) Qualité de l'eau, 6eme édition 2001 tome2: Analyses organoleptiques, mesures physico-chimiques, paramètres globaux, composés organiques.

[16] AFNOR (Association Française de Normalisation) (1994) Qualité de l'eau, lère édition, Paris.

[17] CEAEQ (2011) Détermination des métaux: Méthode par spectrométrie de masse à source ionisante au plasma d'argon, Centre d'Expertise en Analyse Environnementale du Québec.

[18] AFNOR (Association Française de Normalisation) (1996) Microbiologie des aliments: méthode horizontale pour la recherche de Campylobacter thermotolérants. NF ISO 10272. Association Française de Normalisation, 11-14.

[19] Hammer, O., Harper, D.A.T. and Ryan, P.D. (2001) Paleontological Statistics Software Package for Education and Data Analysis. Paleontologica Electronica, 4, 1-9.

[20] Mao, C., Feng, Y., Wang, X. and Ren, G. (2015) Review on Research Achievements of Biogas from Anaerobic Digestion. Renewable. Sustainable. Energy Reviews, 45, 540-555. https://doi.org/10.1016/j.rser.2015.02.032

[21] M'sadak, Y. and Ben M'barek, A. (2015) Caractérisation qualitative d'un digestat avicole liquide issu de la biométhanisation industrielle et valorisation en fertigation des plants de tomate. Larhyss Journal, 21, 51-67.

[22] Goualo, B.C., Djedji, E.B.C. and Kamenan, A. (2007) Etude des caractéristiques chimiques de nouvelles variétés de manioc (Manihot esculenta Crantz). Actes de l'Atelier "Potentialités à la transformation du manioc en Afrique de l'Ouest”-Abidjan, (Côte d'Ivoire), 204-207.

[23] Kpata-Konan, N.E., Gnagne, T., Konan, K.F., Bony, K.Y., Kouamé, K.M., Kouamé, Y.F. and Tano, K. (2013) Improving Anaerobic Biodigestion of Manioc Wastewater with Human Urine as Cosubstrate. International Journal of Innovation and Applied Studies, 2, 335-343.

[24] De La Farge, B. (1995) Le biogaz, procédés de fermentation méthanique. Edition Masson, Coll. Ingénierie de l'environnement, Paris.

[25] Trémier, A., Buffet, J., Picard, S. and Saint-Cast, P. (2014) DIVA-Tâche 3.2 Caractérisation des digestats. Tâche 3.3 Biodégradabilité résiduelle.

[26] Lansing, S., Martin, J.F., Botero, R.B., Nogueira da Silva, T. and Dias da Silva, E. (2010) Methane Production in Low-Cost, Unheated, Plug-Flow Digesters Treating Swine Manure and Used Cooking Grease. Bioresource Technology, 101, 4362-4370. https://doi.org/10.1016/j.biortech.2010.01.100

[27] Frischmann, P. (2012) Enhancement and Treatment of Digestates from Anaerobic Digestion. Working Together for a World without Waste.

http://www.wrap.org.uk/sites/files/wrap/Digestates\%20from\%20Anaerobic\%20Dige stion $\% 20 \mathrm{~A} \% 20$ review $\% 20$ of $\% 20$ enhancement $\% 20$ techniques $\% 20$ and $\% 20$ novel $\% 20$ digestate $\% 20$ products $0 . p d f$

[28] Svoboda, N., Taube, F., Wienforth, B., Kluß, C., Kage, H. and Herrmann, A. (2013) Nitrogen Leaching Losses after Biogas Residue Application to Maize. Soil \& Tillage Research, 130, 69-80. https://doi.org/10.1016/j.still.2013.02.006

[29] Perscheron, F., Perlès, R. and Foglietti, M.J. (1994) Biochimie Strcuraleet Metabolique. Chromoprotéineglucidesglucoproteines. Lipides oxydations biologiques interrelation métabolique. Barcelone, Milan, Paris, 247-249.

[30] Müller, F. and Zdanevitch, I. (2014) Qualité des composts et des digestats. Colloque 
national Prévention \& gestion des déchets dans les territories. Paris, France.

[31] Tao, W., Fattah, K.P. and Huchzermeier, M.P. (2016) Struvite Recovery from Anaerobically Digested Dairy Manure: A Review of Application Potential and Hindrances. Journal of Environmental Management, 169, 46-57.

https://doi.org/10.1016/j.jenvman.2015.12.006

[32] Smith, K.A., Jeffrey, W.A., Metcalfe, A.H, Sinclair, J.R. (2010) Nutrient Value of Digestate from Farm-Based Biogas Plants. In: Ferreira, L. and Cordovil, C., Eds., Treatment and Use of Organic Residues in Agriculture: Challenges and Opportunities toward Sustainable Management. Proceedings of the 14th Ramiran International Conference, Instituto Superior de Agronomia, Universidad Técnica de Lisboa Lisboa, Portugal.

[33] Möller, K. and Müller, T. (2012) Effets of Anaerobic Digestion on Digestate Nutrient Availability and Crop Growth. Engineering in Life Sciences, 12, 242-257. https://doi.org/10.1002/elsc.201100085

[34] Nges, I.A., Wang, B., Cui, Z. and Liu, J. (2015) Digestate Liquor Recycle in Minimal Nutrients-Supplemented Anaerobic Digestion of Wheat Straw. Biochemical Engeeing Journal, 94, 106-114. https://doi.org/10.1016/j.bej.2014.11.023

[35] Bouaroudj, S. and Kadem, D.E.D. (2014) Evaluation of Irrigation Water Quality Wadi: Rhumel and Boumerzoug (Constantine). Revue Scientifique et technique LIEE, 24-25, 36-44.

[36] Besson, M. and Moletta, R. (2010) Aspects sanitaires de l'épandage de digestats issus de méthanisation à la ferme. Résultats issus du rapport de stage de Mylène Besson: La méthanisation en zones AOC Savoyardes. Connaissance et maîtrise des aspects sanitaires liés à l'épandage de digestat. (1) LEGTA de Savoie, Domaine Reinach, (73 290) La Motte Servolex (2) Moletta Méthanisation, 73470 Novalaise. 